\title{
Cyanoacetyl Urea in Heterocyclic Synthesis part V: Facile Synthesis of poly-Functionalized Pyrimdines via Different Behaviors of its Free Urea Amino Group
}

\author{
H.S. Othman ${ }^{1}$, M.A. Hashash ${ }^{2}$, G.A.M. Nawwar ${ }^{1 *}$ \\ ${ }^{1}$ Green Chemistry Department, Chemical Industries Research Division, National \\ Research Centre \\ ${ }^{2}$ Chemistry Department, Faculty of Science, Ain-shams University, Cairo, Egypt.
}

$\mathbf{T}$ HE poly-functional precursor, cyano-acetyl urea, could be utilized in the synthesis of various pyrimidens utilizing its benzothiazole derivative 1 . The free amino group in 1 undergoes different chemical behavior according to the reaction conditions to afford pyrimidines $3,4,5,6,7 \mathrm{a}, \mathrm{b}$ and $9 \mathrm{a}, \mathrm{b}$, respectively.

Keywords: 1,3-Benzothiazole, Pyrimidine, Cyanoacetyl urea, small molecules.

\section{Introduction}

Pyrimidines, an important class of heterocycles, occupy a central position due to their presence in genetic material of cells. They occurred widely in nature as substituted or ring fused compounds including nucleotides, thiamine and alloxan. Pyrimidine moiety is also found in various biologically active synthetic compounds, such as, HIV drug zidovudine[1]. As pyrimidine is a basic nucleus in DNA \& RNA, it has been found to be associated with diverse biological activities and its derivatives have attracted much attention due to their remarkable and prominent pharmacological activity[2].

Among various pyrimidine derivatives, the synthesis of pyrimidine-2,4-diones remains an area of current interest due to the presence of such moiety in a large number of biologically important compounds [3-5]. Recently, we synthesized a superabsorbent which could be used to absorb urea from urine [6] as we are interested in utilizing biomass building block in organic synthesis. We previously prepared cyanoacetyl urea and its benzothiazole derivative $\mathbf{1}$ and used them as versatile precursors for synthesis of many biologically active small molecules [7]. Utility of $\mathbf{1}$ in the synthesis of thymine analogs and condensed aza-heterocycles has been also reported [8]. In continuation, we explored these approaches to prepare other difficulty accessible pyrimidones.

\section{Results and Discussion}

It has been found that when 2-(benzo[d] thiazol-2-yl)-N-carbamoyl acetamide (1) condensed with 4-chloro-benzaldehyde in ethanolic piperidine, it afforded the corresponding arylidene 2 in an excellent yield (Scheme 1). Its ${ }^{1} \mathrm{H}-\mathrm{NMR}$ spectrum showed the ylidene singlet at $\delta 7.9 \mathrm{ppm}$. Its IR spectrum and elemental analysis are in accordance with this structure. In addition, its mass spectral data showed a molecular ion peak $\left(\mathrm{M}^{+}\right)$compatible with its formula $\mathrm{C}_{17} \mathrm{H}_{12} \mathrm{ClN}_{3} \mathrm{O}_{2} \mathrm{~S}$ at $\mathrm{m} / \mathrm{z}=357(30 \%)$.

Compound 2 underwent 1,6-cyclization by refluxing in DMF, in the presence of triethylamine, to afford a product which showed a molecular ion peak similar to that of the parent compound 2. The absence of singlet signal of ylidene proton and the presence of two new doublet signals at $\delta 4.9 \mathrm{ppm}$ and $\delta 5.3 \mathrm{ppm}$, each signal integers to $1 \mathrm{H}$, were shown in its ${ }^{1} \mathrm{H}-\mathrm{NMR}$ spectrum. Accordingly, dihydro pyrimidine structure of compound 3 was given to this obtained product (Scheme 1).

Benzothiazolyl uracil derivative 4, was obtained upon heating compound 1 in triethyl orthoformate. It seems that free urea amino group in the ethoxy ylidine intermediate of 4 prefers replacement of the ethoxy group as eliminated ethanol instead of its addition behavior to afford dihydropyrmidine (3).

Upon refluxing compound 1 in acetic anhydride containing zinc chloride as a catalyst, 
a new compound was obtained. The mass spectrum of this compound showed a molecular ion peak $\left(\mathrm{M}^{+}\right)$as base peak at $\mathrm{m} / \mathrm{z}=301(100 \%)$. Its ${ }^{1} \mathrm{H}-\mathrm{NMR}$ spectrum lacked the characteristic signals of methylene and ureido $\mathrm{NH}_{2}$ [8] and revealed only one $\mathrm{D}_{2} \mathrm{O}$ exchangeable, singlet signal, it also showed benzothiazole signals and two methyl singlet signals at $\delta 2.4 \mathrm{ppm}$ and $\delta 2.6$ ppm, respectively. Based on this information, in addition to its IR spectrum and the microanalytical data, the 4-O-acetylateduracil structure of compound 5 was given to this product [9] (Scheme1). Product 5 was formed via acetylating the active methylene group in compound 1 with subsequent condensation with free amino group.<smiles>[Y]N1C(=O)NC(=O)C(=O)C1c1nc2ccccc2s1</smiles>
$7^{\mathrm{Ar}}$ 7 a, $\mathrm{Ar} r^{\prime}=4-\mathrm{Cl}-\mathrm{C}_{6} \mathrm{H}_{4}$
b, $\mathrm{Ar} r^{\prime}=3,4-(\mathrm{Cl})_{2}-\mathrm{C}_{6} \mathrm{H}_{3}$<smiles>CCO/C=C(/C(=O)NC(N)=O)c1nc2ccccc2s1</smiles>

8

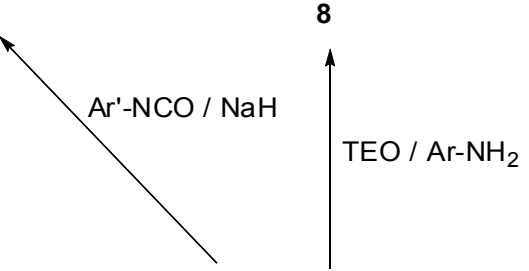<smiles>CC(Cl)n1cc(-c2nc3ccccc3s2)c(=O)[nH]c1=O</smiles>

a, $\mathrm{Ar}=\mathrm{C}_{6} \mathrm{H}_{5}$ b, $\mathrm{Ar}=2-\mathrm{OCH}_{3}-\mathrm{C}_{6} \mathrm{H}_{4}$

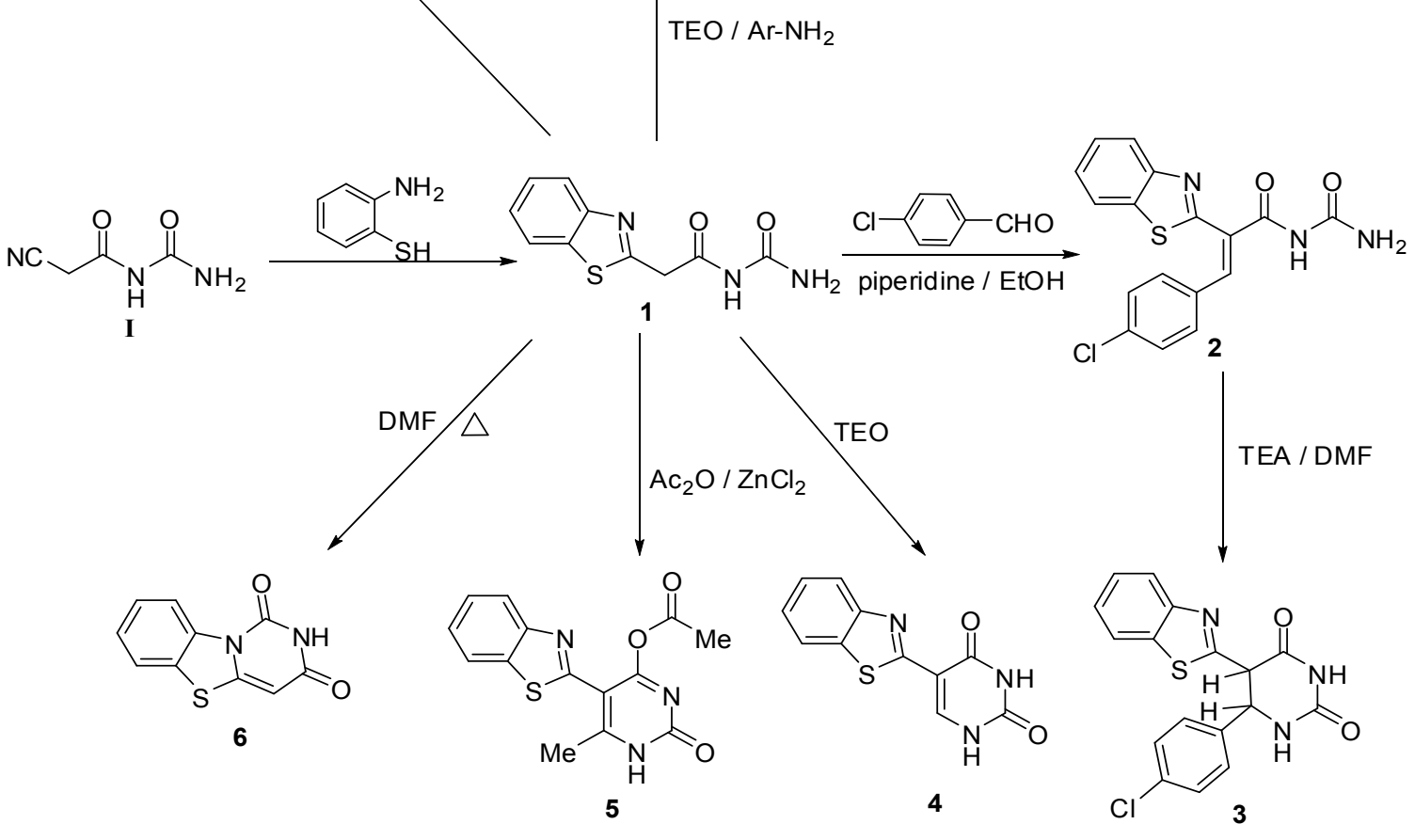

Scheme 1.

On the other hand, when compound $\mathbf{1}$ was refluxed in DMF, a new compound was obtained. Its ${ }^{1} \mathrm{H}-\mathrm{NMR}$ showed the absence of methylene protons signal at $\delta 4.2 \mathrm{ppm}$ in its parent spectrum and it showed also the presence of a signal at 6.2 ppm $(1 \mathrm{H})$ along with one $\mathrm{D}_{2} \mathrm{O}$ exchangeable signal $(1 \mathrm{H})$ at $\delta 11.6 \mathrm{ppm}$. In addition, its IR spectrum revealed the presence of $\mathrm{C}=\mathrm{O}$ absorption peaks while its mass spectral data showed molecular ion peak at $m / z=218(95 \%)$. Based on the previous data, the structure $1 H$-benzo[4,5]thiazolo[3,2-c] pyrimidine-1,3(2H)-dione (6) was established to this product (Scheme 1). Compound $\mathbf{6}$ is assumed to be formed via self cyclization involving the nucleophilic attack of benzothiazole $\mathrm{NH}$ on $\mathrm{C}=\mathrm{O}$ group of the ureido residue with evolution of ammonia, a result in accordance with previous reports [7].

Moreover, when compound 1 was allowed to react with two different aryl isocyanates in dry dimethyl formamide and sodium hydride, new compounds were obtained with evolution of ammonia gas. Their ${ }^{1} \mathrm{H}-\mathrm{NMR}$ showed aromatic 
protons along with $\mathrm{D}_{2} \mathrm{O}$ exchangeable signals. Meantime, their mass spectra gave molecular ion peaks, in each case, equal to the sum of the two reactants minus ammonia. Based on these data, IR spectrum and microanalytical analysis of these products, their structure 5-(benzo[d] thiazol-2yl)-6-hydroxy-1-arylpyrimidine-2,4(1H,3H)dione 7a,b were established (Scheme1). They are assumed to be formed through addition of the active methylene on the corresponding isocyanate to form a 1:1 adduct which subsequently cyclized via elimination of the urea amino group to afford the final product.

Compound 1 was treated with triethyl orthoformate in the presence of aniline in equimolar ratio and a product with molecular formula $\mathrm{C}_{17} \mathrm{H}_{11} \mathrm{~N}_{3} \mathrm{O}_{2} \mathrm{~S}\left(\mathrm{~m} / \mathrm{z}=321, \mathrm{M}^{+} 100 \%\right)$ was obtained. Its ${ }^{1} \mathrm{H}-\mathrm{NMR}$ revealed the absence of the ureido $\mathrm{NH}_{2}$ and active methylene signals and the presence of additional signals of aromatic protons to those of benzothiazole moiety, along with the characteristic singlet $(1 \mathrm{H})$ at $\delta 8.6 \mathrm{ppm}$ similar to that previously detected for the pyrimidine $6-\mathrm{H}$ [8]. These data in addition to the microanalytical analysis caused the 5-(benzothiazole-2-yl) uracil derivative $9 \mathrm{a}$ to be assumed for this product (Scheme 1). Similarly, when the reaction was repeated with $\mathrm{O}$-anisidine, the corresponding derivative $9 \mathrm{~b}$ was obtained in a fairly good yield (Scheme 1). It is assumed that, compound 1 reacted with triethyl orthoformate to give the intermediate 8 which reacted with aniline via loss of ethyl alcohol, and followed by subsequent self cyclization with emission of ammonia to afford the final products 9a,b, a result in accordance with previously reported findings [10]. It is worth to mention that, reaction of 1 with triethyl orthoformate in absence of aniline proceeded via the same intermediate 8 which underwent self cyclization with loss of ethyl alcohol to give compound 4 .

\section{Experimental}

Melting points are uncorrected and were taken on an electrothermal 9100 apparatus; IR spectra were recorded with a Carl Zeiss spectrophotometer, model UR 10 in $\mathrm{KBr}$ pellets. ${ }^{1} \mathrm{H}-\mathrm{NMR}$ spectra were determined with a Jeol instrument (internal TMS). Mass spectra were recorded with Finigan SSQ 7000 mass spectrometer. Microanalysis was performed by the Central Service Laboratory at Cairo University and the Microanalytical Unit at the National Research Centre.
(Z)-2-(Benzo[d]thiazol-2-yl)-N-carbamoyl-3-(4chlorophenyl) acrylamide (2)

Compound 1 (10 mmole, $2.35 \mathrm{~g}$ ) was refluxed with 4-chlorobenzaldehyde (10 mmole, $1.4 \mathrm{~g})$ in ethyl alcohol $(30 \mathrm{ml})$ in presence of piperidine (3 drops) as a catalyst for $2 \mathrm{~h}$. A precipitate was formed during the reaction course, filtered off and crystallized to give compound 2, m.p 226-227 ${ }^{\circ} \mathrm{C}$, yield $85 \%$ (ethanol).

$\mathrm{IR}(\mathrm{KBr}), v / \mathrm{cm}^{-1} 3365-3150 \mathrm{NH}_{2}, \mathrm{NH}, 1730$, $1690(2 \mathrm{C}=\mathrm{O})$.

${ }^{1} \mathrm{H}-\mathrm{NMR}$ [DMSO- $\left.d_{6}\right]$ ( $\mathrm{D}_{2} \mathrm{O}$ exchangeable), $\delta$, 7.10-7.80 (m, 9H, $\mathrm{C}_{6} \mathrm{H}_{4}$, benzothiazole 5- $\mathrm{H}$, 6-H,ylidene $\mathrm{H}$ and $\left.\mathrm{NH}_{2}\right), 8.10-8.30 \quad(\mathrm{~m}, 2 \mathrm{H}$ benzothiazole 4-H and 7-H, $11.00(\mathrm{~s}, 1 \mathrm{H}, \mathrm{NH})$.

MS $m / z \quad\left(\mathbf{M}^{+} 357,30 \%\right)$. Anal. Calcd for $\mathrm{C}_{17} \mathrm{H}_{12} \mathrm{ClN}_{3} \mathrm{O}_{2} \mathrm{~S}$ (357.81): C, 57.06\%; H, 3.38\%; $\mathrm{Cl}, 9.91 \%$; N, 11.74\%; S, 8.96\%.

Found: C, 57.12\%; H, 3.25\%; Cl, 9.78\%; N, $11.62 \%$; S, $8.81 \%$.

\section{5-(Benzo $[d]$ thiazol-2-yl)-6-(4-chlorophenyl)} dihydropyrimidine-2,4(1H,3H)-dione (3):

Compound 2 (10 mmole, $3.57 \mathrm{~g}$ ) was refluxed in dimethylformamide $(10 \mathrm{ml})$ in presence of triethylamine ( 2 drops) as a catalyst for 30 min. The reaction mixture was then partially concentrated, cooled and the solid formed was filtered off, and crystallized to give compound 3 , m.p 267-268 ${ }^{\circ} \mathrm{C}$, yield $20 \%$ (ethanol).

IR(KBr), $v / \mathrm{cm}^{-1} 3250-30802 \mathrm{NH}, 1710,1700$ $(2 \mathrm{C}=\mathrm{O})$.

${ }^{1} \mathrm{H}-\mathrm{NMR}$ [DMSO- $\left.d_{6}\right]$ ( $\mathrm{D}_{2} \mathrm{O}$ exchangeable), $\delta, J=11 \mathrm{~Hz}, 4.90(\mathrm{~d}, 1 \mathrm{H}$, pyrimidine $5-\mathrm{H}), J=11$ $\mathrm{Hz}, 5.25$ (d,1H, Pyrimidine 6H), 7.40-7.60 (m, $6 \mathrm{H}, \mathrm{C}_{6} \mathrm{H}_{4}$, benzothiazole 5-H,6-H), $8.10(\mathrm{~m}, 2 \mathrm{H}$ benzothiazole 4-H and 7-H), $8.70 \mathrm{ppm}(\mathrm{s}, 1 \mathrm{H}, \mathrm{NH})$, 10.60 (s, $1 \mathrm{H}, \mathrm{NH})$. MS $m / z\left(\mathrm{M}^{+} 357,50 \%\right)$.

Anal. Calcd. for $\mathrm{C}_{17} \mathrm{H}_{12} \mathrm{ClN}_{3} \mathrm{O}_{2} \mathrm{~S}$ (357.81): C, $57.06 \% ; \mathrm{H}, 3.38 \% ; \mathrm{Cl}, 9.91 \% ; \mathrm{N}, 11.74 \%$; , $8.96 \%$.

Found: C, 57.13\%; H, 3.29\%; Cl, 9.22\%; N, $11.63 \%$; S, 8.77\%.

5-(Benzo $[d]$ thiazol-2-yl)pyrimidine-2,4- $(1 \mathrm{H}, 3 \mathrm{H})$ dione (4):

Compound 1 (10 mmole, $2.35 \mathrm{~g}$ ) was refluxed in triethylorthoformate $(10 \mathrm{ml})$ for $30 \mathrm{~min}$. After cooling, the formed precipitate was filtered off 
and crystallized to give compound 4, m.p >300 ${ }^{\circ} \mathrm{C}$, yield $70 \%$ (acetic acid).

$\mathrm{IR}(\mathrm{KBr}), v / \mathrm{cm}^{-1} \quad 3200-2800 \quad(2 \mathrm{NH}), 1720$, $1680(2 \mathrm{C}=\mathrm{O})$.

${ }^{1} \mathrm{H}-\mathrm{NMR}$ [DMSO- $\left.d_{6}\right]$ ( $\mathrm{D}_{2} \mathrm{O}$ exchangeable), $\delta$, 7.30-7.50 (m, 2H, benzothiazole 5-H, 6-H), 7.90$8.00(\mathrm{~m}, 2 \mathrm{H}$, benzothiazole $4-\mathrm{H}$ and $7-\mathrm{H}), 8.50$ (s,1H, Pyrimidine 6-H), 11.75, 11.80 (2s, 2H, 2NH).

MS (70ev): $m / z\left(\mathrm{M}^{+} 245,35 \%\right)$.

Anal. Calcd. for $\mathrm{C}_{11} \mathrm{H}_{7} \mathrm{~N}_{3} \mathrm{O}_{2} \mathrm{~S}$ (245.26): C, 53.87\%; H, 2.88\%; N, 17.13\%; S, 13.07\%.

Found: C, 53.62\%; H, 2.72\%; N, $16.09 \%$; , $12.82 \%$

5-(Benzo[d]thiazol-2-yl)-6-methyl-2-oxo-1,2dihydropyrimidine-4-yl acetate (5):

Compound 1 (10 mmole, 2.35g) was refluxed in acetic anhydride $(20 \mathrm{ml})$ containing zinc chloride $(0.5 \mathrm{~g})$ for about $1 \mathrm{~h}$. The precipitate formed during reflux was filtered off and crystallized to give compound 5, m.p $257^{\circ} \mathrm{C}$, yield $30 \%$ (ethyl alcohol).

IR(KBr), $v / \mathrm{cm}^{-1} 3450-3400 \mathrm{NH}, 1685,1640$ $(2 \mathrm{C}=\mathrm{O})$.

${ }^{1} \mathrm{H}-\mathrm{NMR}$ [DMSO- $d_{6}$ ] ( $\mathrm{D}_{2} \mathrm{O}$ exchangeable), $\delta$, $2.40\left(\mathrm{~s}, 3 \mathrm{H}, \mathrm{CH}_{3}\right), 2.60\left(\mathrm{~s}, 3 \mathrm{H}, \mathrm{CH}_{3}\right), 7.50-7.60$ $(\mathrm{m}, 2 \mathrm{H}$, benzothiazole $4-\mathrm{H}$ and $5-\mathrm{H}), 8.10(\mathrm{~m}, 1 \mathrm{H}$, benzothiazole $4-\mathrm{H}), 9.20(\mathrm{~m}, 1 \mathrm{H}$, benzothiazole 7-H), 12.60 (s, 1H, NH).

MS (70ev): $m / z\left(\mathrm{M}^{+} 301,100 \%\right)$.

Anal. Calcd. For $\mathrm{C}_{14} \mathrm{H}_{11} \mathrm{~N}_{3} \mathrm{O}_{3} \mathrm{~S}$ (301.32): C, $55.80 \%$; H, 3.68\%; N, 13.95\%; S, 10.64\%.

Found: C, 55.69\%; H,3.59\%; N, 13.80\%; S, $10.50 \%$.

5-(Benzo[d] thiazolo[3,2-c]pyrimidine-2,4dione (6):

Compound 1 (10mmole, $2.35 \mathrm{~g}$ ) was refluxed in $\mathrm{DMF}(10 \mathrm{ml})$ for $1 \mathrm{~h}$. After partial concentration and cooling, a precipitate was formed, filtered off and crystallized to give compound 6, m.p 287-289 ${ }^{\circ} \mathrm{C}$, yield $80 \%$ (acetic acid).

$\mathrm{IR}(\mathrm{KBr}), \quad v / \mathrm{cm}^{-1} \quad 3430 \mathrm{NH}, \quad 1725,1642$ $(2 \mathrm{C}=\mathrm{O})$.

${ }^{1} \mathrm{H}-\mathrm{NMR}$ [DMSO-d $]$ ( $\mathrm{D}_{2} \mathrm{O}$ exchangeable), $\delta, 6.20(\mathrm{~s}, 1 \mathrm{H}$, Pyrimidine 4-H), 7.30-7.40 (m, $2 \mathrm{H}$, benzothiazole $5-\mathrm{H}$ and $6-\mathrm{H}), 7.90(\mathrm{~m}, 1 \mathrm{H}$, benzothiazole $4-\mathrm{H}), 8.50(\mathrm{~m}, 1 \mathrm{H}$ benzothiazole 7-H), 11.60 (s, 1H, NH).

MS (70ev): m/z (M+218, 95\%).

Anal. Calcd. for $\mathrm{C}_{10} \mathrm{H}_{6} \mathrm{~N}_{2} \mathrm{O}_{2} \mathrm{~S}$ (218.23): C,55.04\%; H, 2.77\%; N, 12.84\%; S, 14.69\%.

Found: C, 54.88\%; H, 2.66\%; N,12.68\%; S, $14.90 \%$.

5-(Benzo[d]thiazol-2-yl)-1-aryl-6-hydroxypyrimidine-2,4(1H,3H)-dione $(7 a, b)$ :

General procedure:

To a solution of compound 1 (10 mmole, $2.35 \mathrm{~g}$ ) in $10 \mathrm{ml}$ dry DMF in the presence of sodium hydride $(10 \mathrm{mmol})$ at $50{ }^{\circ} \mathrm{C}$, a solution of the proper arylisocyanate $(10 \mathrm{mmole})$ in $5 \mathrm{ml}$ dry DMF was dropped over within $30 \mathrm{~min}$. with stirring. Stirring was kept for further $1 \mathrm{~h}$., then $\mathrm{HCl}(50 \% \mathrm{v} / \mathrm{v})$ was added to the reaction mixture till neutralization. Thus, precipitate was formed, filtered off, washed with warm water and finally crystallized.

5-(Benzo[d]thiazol-2-yl)-1-(4-chlorophenyl)-6hydroxypyrimidine-2,4(1H,3H)-dione $(7 a)$ :

m.p $>300{ }^{\circ} \mathrm{C}$, yield 85\% (DMF).

IR(KBr $), v / \mathrm{cm}^{-1} \quad 3470-3100 \mathrm{NH}, \mathrm{OH}, 1745$, $1670(2 \mathrm{C}=\mathrm{O})$.

${ }^{1} \mathrm{H}-\mathrm{NMR}$ [DMSO- $d_{6}$ ] ( $\mathrm{D}_{2} \mathrm{O}$ exchangeable), $\delta$, 7.30-7.70 (m, 6H, $\mathrm{C}_{6} \mathrm{H}_{4}$ and benzothiazole $5-\mathrm{H}$ and $6-\mathrm{H}), 8.00(\mathrm{~m}, 1 \mathrm{H}$ benzothiazole $4-\mathrm{H}), 8.60$ $(\mathrm{m}, 1 \mathrm{H}$ benzothiazole $7-\mathrm{H}), 11.50(\mathrm{~s}, 1 \mathrm{H}, \mathrm{NH})$, $12.50(\mathrm{~s}, 1 \mathrm{H}, \mathrm{OH})$.

MS (70ev): $m / z\left(\mathrm{M}^{+} 371,40 \%\right)$.

Anal. Calcd. for $\mathrm{C}_{17} \mathrm{H}_{10} \mathrm{ClN}_{3} \mathrm{O}_{3} \mathrm{~S}$ (371.80): C, 54.92\%; H, 2.71\%; Cl, 9.54\%; N, $11.30 \%$; $\mathrm{S}, 8.62 \%$.

Found: C, 54.81\%; H, 2.65\%; Cl, 9.43\%; N, $11.15 \%$; S, $8.52 \%$.

5-(Benzo[d]thiazol-2-yl)-1-(3,4-dichlorophenyl)6-hydroxypyrimidine-2,4(1H, 3H)-dione (7b):

m.p $>300{ }^{\circ} \mathrm{C}$, yield $85 \%$ (DMF).

$\mathrm{IR}(\mathrm{KBr}), v / \mathrm{cm}^{-1} 3450-3100 \mathrm{NH}, \mathrm{OH}, 1740$, $1680(2 \mathrm{C}=\mathrm{O})$.

${ }^{1} \mathrm{H}-\mathrm{NMR}\left[\mathrm{DMSO}-d_{6}\right]$ ( $\mathrm{D}_{2} \mathrm{O}$ exchangeable $), \delta$, 7.40-8.20 (m, 6H, $\mathrm{C}_{6} \mathrm{H}_{3}$ and benzothiazole 5- $\mathrm{H}$, $6-\mathrm{H}$ and $4-\mathrm{H}), 8.60(\mathrm{~m}, 1 \mathrm{H}$ benzothiazole $7-\mathrm{H})$, 11.50 (s,1H,NH), 12.50 (s,1H,OH). 
MS (70ev): $m / z\left(\mathrm{M}^{+} 406,20 \%\right)$.

Anal. Calcd. for $\mathrm{C}_{17} \mathrm{H}_{9} \mathrm{Cl}_{2} \mathrm{~N}_{3} \mathrm{O}_{3} \mathrm{~S}$ (406.24): C, $50.26 \% ; \mathrm{H}, 2.23 \% ; \mathrm{Cl}, 17.45 \% ; \mathrm{N}, 10.34 \%$; S, $7.89 \%$.

Found: C, 50.12\%; H, 2.19\%; Cl, 17.31\%; N, $10.28 \%$; S, $7.69 \%$.

1-Aryl-5-(benzothiazol-2-yl)--3H -pyrimidine2,4-dione $(9 a, b)$.

Compound 1 (10mmole, $2.35 \mathrm{~g}$ ) was refluxed with the appropriate aniline derivative (10 mmole) and triethylortho formate (10 mmole, $1.48 \mathrm{~g})$ in dry dimethylformamide $(10 \mathrm{ml})$ for $2 \mathrm{~h}$. The precipitate formed during the reaction course was filtered off and crystallized.

5-(Benzo[d]thiazol-2-yl)-1-phenylpyrimidine2,4-(1H,3H)-dione (9a):

m.p $>300{ }^{\circ} \mathrm{C}$, yield $75 \%$ (DMF).

IR(KBr), $v / \mathrm{cm}^{-1} 3450-3350 \mathrm{NH}, 1740,1685$ $(2 \mathrm{C}=\mathrm{O})$.

${ }^{1} \mathrm{H}-\mathrm{NMR}$ [DMSO- $\left.d_{6}\right]$ ( $\mathrm{D}_{2} \mathrm{O}$ exchangeable), $\delta, 7.40-7.65\left(\mathrm{~m}, 7 \mathrm{H}, \mathrm{C}_{6} \mathrm{H}_{5}\right.$ and benzothiazole 5-H, and 6-H), 7.90 (m, 1H benzothiazole 4-H), $8.20(\mathrm{~m}, 1 \mathrm{H}$ benzothiazole $7-\mathrm{H}), 8.65(\mathrm{~s}, 1 \mathrm{H}$, Pyrimidine 6-H), 12.25(s, 1H, NH).

MS (70ev): $m / z\left(\mathrm{M}^{+} 321,100 \%\right)$.

Anal. Calcd. for $\mathrm{C}_{17} \mathrm{H}_{11} \mathrm{~N}_{3} \mathrm{O}_{2} \mathrm{~S}$ (321.35): C, $63.54 \%$; H, 3.45\%; N, 13.08\%; S, 9.98\%.

Found: C, 63.42\%; H, 3.30\%; N, 13.18\%; S, $9.80 \%$.

5-(Benzo[d]thiazol-2-yl)-1-(2-methoxyphenyl) pyrimidine-2,4(1H,3H)dione $(9 \mathrm{~b})$ :

m.p $>300{ }^{\circ} \mathrm{C}$, yield $80 \%$ (DMF).

$\mathrm{IR}(\mathrm{KBr}), v / \mathrm{cm}^{-1} 3450-3360 \mathrm{NH}, 1735,1690$ $(2 \mathrm{C}=\mathrm{O})$.

${ }^{1} \mathrm{H}-\mathrm{NMR}$ [DMSO- $d_{6}$ ] (D $\mathrm{D}$ exchangeable), $\delta$, 7.20-7.70 (m,6 $\mathrm{H}_{2} \mathrm{C}_{6} \mathrm{H}_{4}$ and benzothiazole 5- $\mathrm{H}$, and 6-H), 7.90 ( $\mathrm{m}, 1 \mathrm{H}$ benzothiazole 4-H), 8.10 (m,1H benzothiazole 7-H), 8.60 (s,1H, Pyrimidine 6-H), 12.30 (s,1H,NH).

MS (70ev): $m / z\left(\mathrm{M}^{+} 351.07,100 \%\right)$.

Anal. Calcd. for $\mathrm{C}_{18} \mathrm{H}_{13} \mathrm{~N}_{3} \mathrm{O}_{3} \mathrm{~S}$ (351.38): C, $61.53 \%$; H, 3.73\%; N, 11.96\%; S, 9.13\%.

Found: C, 61.39\%; H, 3.66\%; N, 11.81\%; S, $8.99 \%$.

\section{References}

1. Karbanova, S., Cerveny, L., Ceckova, M, Ptackova, Z., Jiraskova, L., Greenwood, S., Staud, F. Role, of Nucleoside Transporters in Transplacental Pharmacokinetics of Nucleoside Reverse Transcriptase Inhibitors Zidovudine and Emtricitabine.Placenta, 60, 86 (2017).

2. Merugu, R., Garimella, S., Balla, D., Sambaru K.. Synthesis, and Biological Activities of Pyrimidines: A Review. International Journal of Pharm Tech Research. 8,88 (2015).

3. Ismail, Kuthati B., Thalari, G., Bommarapu ,V., Mulakayala C, Chitta SK, Mulakayala N. Synthesis of novel spiro[pyrazolo[4,3-d] pyrimidinones and spiro[benzo[4,5] thieno[2,3-d]pyrimidine-2,3'-indoline]2',4(3H)-diones and their evaluation for anticancer activity. Bioorganic Med. Chem. Lett. 27, 1446 (2017).

4. Kankanala, J., Kirby, K.A., Huber, A.D., Casey , M.C., Wilson, D.J., Sarafianos, S.G., Wang, Z. Design, synthesis and biological evaluations of N-Hydroxythienopyrimidine-2,4-diones as inhibitors of HIV reverse transcriptase-associated RNase H. Eur. J. Med. Chem. 141, 149 (2017).

5. Design, synthesis and biological evaluations of N-Hydroxythienopyrimidine-2,4-diones as inhibitors of HIV reverse transcriptaseassociated RNase H. Eur. J. Med. Chem. 141, 149 (2017).

6. Tang, J., Maddali , K., Dreis, C.D., Sham, Y.Y., Vince, R., Pommier, Y., Wang, Z. N-3 Hydroxylation of Pyrimidine-2,4-diones Yields Dual Inhibitors of HIV Reverse Transcriptase and Integrase. ACS Medicinal Chemistry Letters. 2, 63 (2011).

7. Ibrahim, S., Nawwar, G.A.M., Sultan, M.Z. Development of bio-based polymeric hydrogel: Green, sustainable and low cost plant fertilizer packaging material. Journal of Environmental Chemical Engineering, 4, 203 (2016).

8. Allam, Y.A., Swellem, R.H., Nawwar, G.A.M.. Cyanoacetylurea in Heterocyclic Synthesis: Part III:"Simple Synthesis of condensed Uracis. Journal of Chemical Research, 8, 346 (2001).

Egypt.J.Chem. 61 , No.1 (2018) 
9. Allam, Y.A., Chabaka, L.M., Nawwar, G.A.M. Activated Nitrile in Heterocyclic Synthesis: Facile Synthesis of Heteroaryl Thiamine Analogues and their Nucleosides. Heteroatom Chemistry,11, 209 (2000).

10. Kanatomo, S., Hase, T., Nagai, S. Sparsomycin Analogs. I. Synthesis of 5-Carboxy-6-methyluracil. Chemical and Pharmaceutical Bulletin. 29, 229 (1981).
11. Nawwar, G.A.M., Yakout, S, El-Sadiek, M.S.A., El-Sabbagh S. Synthesis and Evaluation of New Antioxidants for Styrene Butadiene Rubber. Pigment\& Resin Technology,40,399 ( 2011).

(Received 12/12/2017; accepted 22/1/2018)

$$
\begin{aligned}
& \text { سيانو أسيتيل يوريا فى تخليق حلقات غير متجانسة (الجزء الخامس): تخليق سهل الخهل }
\end{aligned}
$$

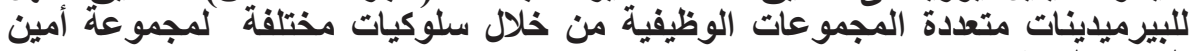

$$
\begin{aligned}
& \text { اليوريا الحرة }
\end{aligned}
$$

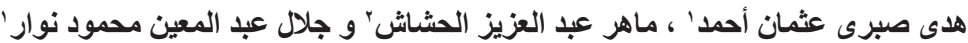

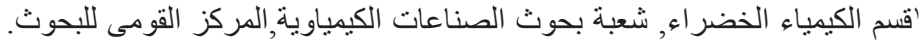

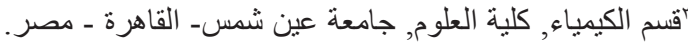

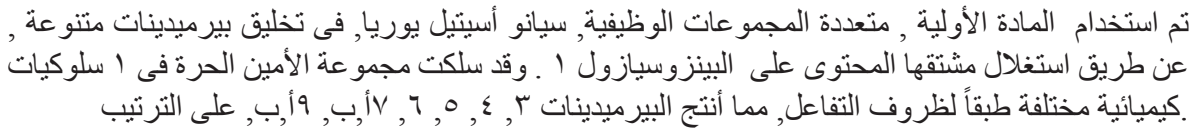

